RESEARCH ARTICLE

\title{
Effect of Period of Soil Moisture Stress at Panicle Initiation and Flowering Stages on Nutrient Uptake and Post-Harvest Soil Nutrient Status in Rice
}

\author{
Girija Prasad Patnaik*, Thavaprakaash $\mathbf{N}^{\mathbf{1}}$, Djanaguiraman $\mathbf{M}^{\mathbf{2}}$ and Senthil Kumar $\mathbf{G}^{\mathbf{1}}$ \\ ${ }^{1 *}$ Department of Agronomy, Tamil Nadu Agricultural University, Coimbatore - 641003 \\ ${ }^{2}$ Department of Crop Physiology, Tamil Nadu Agricultural University, Coimbatore - 641003
}

Received : $17^{\text {th }}$ June, 2020

Revised : $21^{\text {st }}$ July, 2020

Revised : $18^{\text {th }}$ August, 2020

Accepted : $04^{\text {th }}$ September, 2020

\begin{abstract}
A field study was conducted to quantify the effect of moisture stress on nutrient uptake and post-harvest available soil nutrient status of rice in Tamil Nadu Agricultural University, Coimbatore during Kuruvai (July-November) 2019 and Navarai (December-March) 2019-20 seasons. Nine treatments, viz., Moisture stress at panicle initiation stage for 10 days $\left(T_{1}\right), 15$ days $\left(T_{2}\right)$, 20 days $\left(T_{3}\right)$ and 25 days $\left(T_{4}\right)$, moisture stress at flowering stage for 10 days $\left(T_{5}\right), 15$ days $\left(T_{6}\right), 20$ days $\left(T_{7}\right)$ and 25 days $\left(T_{8}\right)$ along with control - maintaining saturation $\left(\mathrm{T}_{9}\right)$ were tested under randomized complete block design with three replications. Moisture stress was imposed by withdrawing water and not irrigating in the defined period. The result showed that significantly higher total drymatter production and N, P and K nutrient uptake (grain, straw and total) during both the seasons were observed in $T_{9}$ treatment than all other moisture stress imposed treatments. The least uptake of $\mathrm{N}$, $\mathrm{P}$ and $\mathrm{K}$ in grain, straw and total was recorded in $\mathrm{T}_{4}$ and was statistically at par with $\mathrm{T}_{3}$. There was reverse trend on post-harvest soil nutrient status (NPK). The study revealed that moisture stress was more sensitive during panicle initiation stage than flowering stage, which directly influenced the uptake of nutrients in rice and there was a reverse trend on post-harvest soil available nutrients (NPK).
\end{abstract}

Keywords: Rice, soil moisture stress, panicle initiation stage, flowering stage, nutrient uptake, postharvest available soil nutrients.

\section{INTRODUCTION}

Rice, mostly as paddy, grows on 163 million ha of the world's surface, the world's most important for food production and security (Goswami et al., 2019). Asian countries account more than 90 per cent of the total rice production and consumption of the world. India has the highest area under rice (43.5 mha) with a production of about $112 \mathrm{mt}$ (NRRI, 2018). It is estimated that 40 per cent increase in rice production is needed to meet the surging demand for the rapidly increasing population by the end of 2030 (FAO, 2009).

Among abiotic stresses, drought or moisture stress cause significant decrease in rice productivity. Drought stress in plants is considered by the continuous water loss via transpiration of restricted water uptake due to reduction in soil moisture (Koffler et al., 2014). Abiotic stress specifically moisture stress has emerged as the biggest bottleneck of irrigated agriculture. Due to drought, there is a decrease in soil moisture, which affects the drymatter production. Germani et al. (2016) observed the reduction of drymatter production when water stress was at tillering to panicle initiation stage. Moisture stress inhibits the cellular physiological processes which ultimately reflects in terms of drymatter accumulation. The reduction in the drymatter is directly proportional to the degree and severity of stress

Nutrient uptake is the product of drymatter accumulation and nutrient content, reduction in drymatter would influence on the nutrient uptake pattern of rice. There would be an inverse relationship between nutrient uptake pattern and post-harvest soil nutrient status. Hence, lesser the absorption of nutrients (low uptake) due to lesser drymatter accumulation; more would be the available nutrients in the soil. As there has been an increased interest to study the growth of rice plant under moisture stress environment, the present field study was formulated to know the nutrient uptake and nutrient removal of rice crop due to the moisture stress. $107|7-9| 1$ 


\section{MATERIAL AND METHODS}

\section{Experimental location}

A field investigation was under taken to investigate the effect of moisture stress at panicle initiation and flowering stages of rice at different periods on nutrient uptake and available nutrients after the harvest of rice. To pursue the objective, the experiment was carried out in two seasons viz., Kuruvai (July - November, 2019) and Navarai (December, 2019 - March, 2020) at Wetland farms, Department of Agronomy, Tamil Nadu Agricultural University, Coimbatore (11' $\mathrm{N}$ and $77^{\prime} \mathrm{E}$ at an altitude of $426.7 \mathrm{~m}$ above MSL and with annual average rainfall of $673 \mathrm{~mm}$ ), Tamil Nadu, India. The soil of the experimental site is Typic Haplustalf and belongs to the Noyyal series. The surface soil (0-30 cm depth) was clay loam in texture and alkaline in reaction $(\mathrm{pH}$ of 7.8-8.2). Organic carbon status of the soil was medium $(0.67-0.70 \mathrm{~g} / \mathrm{kg})$ with low in available nitrogen (213-238 mg/kg), high in both available phosphorus $(47.2-42.0 \mathrm{mg} / \mathrm{kg})$ and available potassium (643-1045 mg/kg).

\section{Treatment details}

The experiment was set up with Randomized Complete Block Design (RCBD) with nine treatments, which were replicated thrice. The treatments were $T_{1}$ - moisture stress (MS) for 10 days at panicle initiation (PI) stage, $T_{2}$ - MS for 15 days at PI stage, $\mathrm{T}_{3}$ - MS for 20 days at PI stage, $\mathrm{T}_{4}$-MS for 25 days at PI stage, $T_{5}-$ MS for 10 days at flowering (FL) stage, $T_{6}-M S$ for 15 days at FL stage, $T_{7}-M S$ for 20 days at FL stage, $T_{8}$ - MS for 25 days at FL stage, $\mathrm{T}_{9}$ - maintaining saturation of water for entire life period as in SRI (Control). The gross plot size of the treatment was $20 \mathrm{~m}^{2}$ with a buffer channel all four sides of the plot.

\section{Rice cultivation}

A short duration (105-110 days) variety, Rice CO 51 released from Tamil Nadu Agricultural University was the test variety. Rice seedlings were raised in a mat nursery. All other cultivation practices were followed as per CPG (2012).

\section{Water stress in field condition}

Moisture stress was imposed at PI stage by withdrawing the water and not irrigating for 10, 15, 20 and 25 days for the treatments $T_{1}, T_{2}, T_{3}$ and $T_{4}$, respectively. Similarly, during FL stage also, water from the experimental plots was drained-off initially and not given irrigation for the period of 10, 15, 20 and 25 days for the treatments $T_{5}, T_{6}, T_{7}$ and $T_{8}$, respectively. After the moisture stress period in the respective treatments, irrigation was given to relieve the moisture stress in both the stages. The field seepage was arrested by the buffer channel and by inserting polythene sheet of about one foot. The treatment $\mathrm{T}_{9}$ was irrigated as followed in SRI method.

\section{Total drymatter}

Randomly tagged five plants were harvested from the ground and dry weights were averaged for individual treatments after drying in hot air oven at $70^{\circ} \mathrm{C}$ for 24 hours till concordant weights were obtained, converted into $\mathrm{kg} / \mathrm{ha}$ for both of the seasons, and tabulated.

\section{Plant nutrient uptake}

The randomly tagged five plants were harvested from net plot separately from each treatment. These were oven dried at $70^{\circ} \mathrm{C}$. The grain and straw were grinded separately and analyzed for total plant uptake of nitrogen $(\mathrm{N})$, phosphorus $(\mathrm{P})$ and potassium $(\mathrm{K})$ by using standard procedure. By cumulating both the grain and straw nutrient uptake, the total nutrient uptake was arrived. The uptake of nutrients was calculated using the following formula.

Nutrient uptake by grain $(\mathrm{kg} / \mathrm{ha})=($ Percentage of nutrient $x$ weight of drymatter of grain $(\mathrm{kg} / \mathrm{ha}) / 100$

Nutrient uptake by straw $(\mathrm{kg} / \mathrm{ha})=($ Percentage of nutrient $x$ weight of drymatter of straw $(\mathrm{kg} / \mathrm{ha}) / 100$

\section{Post-harvest available soil analysis}

The post-harvest samples were collected for analysis at 0-30 cm depth individually from each treatment plots. For collection of samples, ten places were selected in each treatment randomly after harvest of crop. Then samples were composited treatment-wise and taken for analysis. Soil available nitrogen (kg/ha), available phosphorus (kg/ha) and available potassium ( $\mathrm{kg} / \mathrm{ha}$ ) were analyzed using standard procedure.

\section{Data analysis}

The data recorded were analyzed following the standard statistical procedure as described by Gomez and Gomez (2010) to draw valid conclusions.

\section{RESULTS AND DISCUSSION}

\section{Total drymatter}

Significant variation was observed on the total drymatter production of rice due to moisture stress both at panicle initiation (PI) and flowering (FL) stages (Table 1). Significantly higher drymatter was produced in the rice plants supplied with continuous moisture throughout the crop period $\left(T_{9}\right)$ which was followed by $T_{5}$ (Moisture stress for 10 days at FL stage). The drymatter persistently increased in $T_{9}$ treatment in both the seasons which was mainly due to continuous supply of water and possible nutrient supply throughout its life cycle. Treatment $\mathrm{T}_{4}$ produced the least TDMP ( $\left.\mathrm{kg} / \mathrm{ha}\right)$ in both the seasons due to prolonged moisture stress period of 
25 days at $\mathrm{PI}$ stage. Moisture stress was given at the young stage where the plant still in actively growing condition and due to lack of water, the physiological parameters especially photosynthesis might have reduced in the leaves.

Table 1. Effect of moisture stress on total drymatter production of rice

\begin{tabular}{lrr}
\hline \multirow{2}{*}{ Treatments } & \multicolumn{2}{c}{ Total drymatter (kg/ha) at harvest } \\
\cline { 2 - 3 } & Kuruvai 2019 & Navarai \\
\hline $\mathrm{T}_{1}$ & $12939-20$ \\
$\mathrm{~T}_{2}$ & 8809 & 12458 \\
$\mathrm{~T}_{3}$ & 8089 & 7635 \\
$\mathrm{~T}_{4}$ & 7655 & 6690 \\
$\mathrm{~T}_{5}$ & 12395 & 5757 \\
$\mathrm{~T}_{6}$ & 11341 & 12599 \\
$\mathrm{~T}_{7}$ & 10646 & 12414 \\
$\mathrm{~T}_{8}$ & 9608 & 11789 \\
$\mathrm{~T}_{9}$ & 14571 & 9962 \\
$\mathrm{SEd}$ & 485 & 13589 \\
$\mathrm{CD}(\mathrm{P}=0.05)$ & 1029 & 446 \\
\hline
\end{tabular}

Though $\mathrm{T}_{8}$ treatment had a stress period 25 days but at later stage i.e. at flowering stage, it had lesser effect because by the time of stress imposement; the plants completed their full growth. Present study is in conformity with the investigations of Jiang et al. (2018).

\section{Nutrient uptake}

The nitrogen uptake estimated in grain, straw and total plant was varied significantly due to imposing of moisture stress during both $\mathrm{PI}$ and flowering FL stages (Table 2). Generally, the grain nutrient content was always higher than the straw nutrient content. The increasing duration of moisture stress (from 10 days to 25 days) had reduced the nitrogen uptake of grain, straw and total in both $\mathrm{PI}$ and FL stages of rice. Uptake of nutrient by the grain was significantly higher $(104.4 \mathrm{~kg} / \mathrm{ha}$ and $95.1 \mathrm{~kg} / \mathrm{ha}$ ) during Kuruvai and Navarai seasons, respectively in the treatment $\mathrm{T}_{9}$ compared to all the moisture stress imposed treatments. The nutrient uptake was in declining trend when the moisture stress period was increased from 10 days to 25 days (i.e. from $\mathrm{T}_{1}$ to $\mathrm{T}_{4}$ at PI stage; and $\mathrm{T}_{5}$ to $\mathrm{T}_{8}$ at $\mathrm{FL}$ stage). The minimum nitrogen was foraged by rice grains (45.3 kg/ha and $31.4 \mathrm{~kg} / \mathrm{ha}$ during Kuruvai and Navarai seasons, respectively) in the treatment was with the maximum moisture stress period (25 days) during PI stage $\left(\mathrm{T}_{4}\right)$. However, the nutrient uptake values obtained in $T_{4}$ was statistically at par with $\mathrm{T}_{3}$ which indicated that, moisture stress at PI stage for the period of 20 days and 25 days were equally detrimental on nutrient uptake by the rice grains. The same trend of results was observed with the nitrogen uptake of straw and total plant. The total nitrogen uptake in $T_{4}$ was 51.3 per cent lower than that of $T_{9}$ whereas, the reduction was only 38.7 per cent in $T_{8}$ than of $T_{9}$ indicating more detrimental effect of PI stage than FL stage even though, duration of the moisture stress period is same.

Table 2. Effect of moisture stress at critical stages on nitrogen uptake $(\mathrm{kg} / \mathrm{ha})$ of rice

\begin{tabular}{|c|c|c|c|c|c|c|}
\hline \multirow[t]{2}{*}{ Treatments } & \multicolumn{3}{|c|}{ Kuruvai, 2019} & \multicolumn{3}{|c|}{ Navarai, 2019-20 } \\
\hline & Grain & Straw & Total & Grain & Straw & Total \\
\hline$T_{1}$ & 83.5 & 46.9 & 130.4 & 75.0 & 44.4 & 119.4 \\
\hline $\mathrm{T}_{2}$ & 52.3 & 35.4 & 87.7 & 38.4 & 32.9 & 71.3 \\
\hline $\mathrm{T}_{3}$ & 47.7 & 31.2 & 78.9 & 32.9 & 28.8 & 61.7 \\
\hline $\mathrm{T}_{4}$ & 45.3 & 29.1 & 74.5 & 31.4 & 26.8 & 58.2 \\
\hline $\mathrm{T}_{5}$ & 79.6 & 43.4 & 123.0 & 73.9 & 41.2 & 115.1 \\
\hline $\mathrm{T}_{6}$ & 74.8 & 41.1 & 115.9 & 65.2 & 38.8 & 104.0 \\
\hline $\mathrm{T}_{7}$ & 65.0 & 38.9 & 103.9 & 55.7 & 36.7 & 92.4 \\
\hline $\mathrm{T}_{8}$ & 58.4 & 35.4 & 93.8 & 51.5 & 33.1 & 84.6 \\
\hline $\mathrm{T}_{9}$ & 104.4 & 48.5 & 152.9 & 95.1 & 45.9 & 141.0 \\
\hline SEd & 2.8 & 2.4 & 5.8 & 2.8 & 1.8 & 4.4 \\
\hline$C D(P=0.05)$ & 5.9 & 5.1 & 12.2 & 6.0 & 3.9 & 9.4 \\
\hline
\end{tabular}

Similar trend was observed in case of phosphorus and potassium uptake (Table 3 and 4 ) in respect to grain, straw and total plant as in case of nitrogen uptake.

Among the two stages, devoid of moisture at PI stage proved to be more limiting on plant uptake (grain, straw and total) than that of FL stage. The devoid of moisture at PI stage reduced more drymatter accumulation in drought imposed treatments. Even though there was no much variation in the nutrient content between the treatments (data not shown), due to the poor drymatter accumulation in the stress imposed treatments in both PI and FL stages, responded on the nutrient uptake. Similarly 
Havlin et al. (1997). Liu et al. (2013) observed lesser uptake of nitrogen under moisture stress.

The phosphorus and potassium are transported through diffusion; for which moisture is pre-requisite. As the moisture imposed treatments were with less of moisture, obliviously reduces the mobilization of nutrients such as phosphorus and potassium which in turn influenced on the nutrient uptake of both $P$ and $\mathrm{K}$. The panicle initiation stage proved to be the most sensitive for water stress and there was drastic reduction in drymatter and subsequently uptake.

Table 3. Effect of moisture stress at critical stages on phosphorus (kg/ha) uptake of rice

\begin{tabular}{|c|c|c|c|c|c|c|}
\hline & \multicolumn{3}{|c|}{ Kuruvai, 2019} & \multicolumn{3}{|c|}{ Navarai, 2019-20 } \\
\hline & Grain & Straw & Total & Grain & Straw & Total \\
\hline $\mathrm{T}_{1}$ & 11.6 & 18.1 & 29.7 & 10.6 & 17.2 & 27.8 \\
\hline $\mathrm{T}_{2}$ & 8.5 & 15.2 & 23.7 & 6.3 & 14.2 & 20.6 \\
\hline $\mathrm{T}_{3}$ & 7.8 & 14.8 & 22.7 & 5.6 & 13.8 & 19.3 \\
\hline $\mathrm{T}_{4}$ & 7.2 & 13.6 & 20.7 & 5.1 & 12.5 & 17.7 \\
\hline $\mathrm{T}_{5}$ & 11.8 & 19.6 & 31.4 & 11.0 & 18.6 & 29.6 \\
\hline $\mathrm{T}_{6}$ & 11.7 & 17.8 & 29.5 & 10.2 & 16.9 & 27.1 \\
\hline $\mathrm{T}_{7}$ & 9.5 & 16.8 & 26.3 & 8.1 & 15.9 & 24.1 \\
\hline $\mathrm{T}_{8}$ & 8.5 & 14.4 & 22.9 & 7.5 & 13.6 & 21.1 \\
\hline $\mathrm{T}_{9}$ & 15.2 & 20.1 & 35.4 & 13.9 & 19.2 & 33.0 \\
\hline SEd & 0.7 & 0.9 & 1.4 & 0.4 & 1.0 & 1.3 \\
\hline $\mathrm{CD}(\mathrm{P}=0.05)$ & 1.4 & 1.9 & 3.1 & 0.8 & 2.2 & 2.7 \\
\hline
\end{tabular}

Higher uptake of phosphorus and potassium in treatment $T_{9}$ was attributed to the higher soil moisture content, which might have facilitated better diffusion of phosphorus and potassium. In addition to that, maximum drymatter accumulation was noted in $\mathrm{T}_{9}$ treatment, due to the continuous availability of moisture joined together enhanced the chance for increased nutrient uptake of both phosphorus and potassium. Similar results were found by Kaleeswari et al. (2012).

Table 4. Effect of moisture stress at critical stages on potassium uptake $(\mathrm{kg} / \mathrm{ha})$ of rice

\begin{tabular}{lrrrrrr}
\hline \multirow{2}{*}{ Treatments } & \multicolumn{2}{c}{ Kuruvai, 2019 } & \multicolumn{3}{c}{ Navarai, 2019-20 } \\
\cline { 2 - 6 } & \multicolumn{1}{c}{ Grain } & \multicolumn{1}{c}{ Straw } & Total & Grain & Straw & \multicolumn{1}{c}{ Total } \\
\hline $\mathrm{T}_{1}$ & 64.9 & 88.1 & 153.1 & 58.7 & 83.7 & 142.4 \\
$\mathrm{~T}_{2}$ & 45.3 & 68.2 & 113.5 & 33.5 & 63.8 & 97.2 \\
$\mathrm{~T}_{3}$ & 40.9 & 63.0 & 103.9 & 28.6 & 58.6 & 87.2 \\
$\mathrm{~T}_{4}$ & 38.8 & 60.1 & 98.9 & 27.3 & 55.7 & 82.9 \\
$\mathrm{~T}_{5}$ & 65.1 & 86.8 & 151.9 & 60.7 & 78.5 & 139.2 \\
$\mathrm{~T}_{6}$ & 57.0 & 79.8 & 136.8 & 49.9 & 71.4 & 121.3 \\
$\mathrm{~T}_{7}$ & 54.1 & 77.1 & 131.2 & 46.7 & 68.8 & 115.5 \\
$\mathrm{~T}_{8}$ & 45.1 & 67.6 & 112.7 & 40.1 & 59.2 & 99.3 \\
$\mathrm{~T}_{9}$ & 77.4 & 95.2 & 172.6 & 70.9 & 86.1 & 157.0 \\
$\mathrm{SEd}$ & 2.5 & 3.3 & 6.1 & 2.8 & 3.1 & 5.2 \\
$\mathrm{CD}(\mathrm{P}=0.05)$ & 5.2 & 7.0 & 12.9 & 5.8 & 6.6 & 11.1 \\
\hline
\end{tabular}

\section{Post-harvest nutrient status}

The post-harvest available soil nutrient status was significantly affected by the moisture stress treatments in both the seasons, viz., Kuruvai, 2019 and Navarai, 2019-20 (Fig. 1 and 2). Generally, increased the duration of moisture stress (15 or 20 or 25 days) either in PI stage or in FL stage, the left out nutrients ( $N, P$ and $K$ ) in the soil after the harvest of rice was more compared to lesser duration of moisture stress (10 days). Whereas, the least soil available $\mathrm{N}, \mathrm{P}$ and $\mathrm{K}$ were noted in the control, which was maintained with complete saturation without any moisture stress.
During both Kuruvai and Navarai seasons, the available nitrogen content in the soil was significantly higher $(273.8 \mathrm{~kg} / \mathrm{ha}$ and $278.6 \mathrm{~kg} / \mathrm{ha}$, respectively) in the treatment $\mathrm{T}_{4}$ which was given with moisture stress for 25 days during the PI stage. However, it was on par with $\mathrm{T}_{3}$ (20 days of moisture stress during PI stage) than to all other water stress treatments and control. Increased value of soil available nitrogen in these treatments might be due to the poor drymatter accumulation and poor recovery after moisture stress (20-25 days during PI stage) which led to reduced the nutrient uptake of nitrogen as evidenced in the present study (Table 2). Reduced uptake of nitrogen obliviously leaves more nitrogen 
in the soil in these treatments. The control $\left(T_{9}\right)$ treatment, which left the minimum nitrogen in the soil among all, was mainly due to absorption of more nitrogen by the rice plant (Table 2). Continuous supply of moisture in control treatment produced more biomass and gave a chance to absorb the nitrogen without any hindrance in turn promoted more nutrient uptake and the least available nitrogen in the soil. Haefele et al. (2008) and Teronpi and Bharali (2019) expressed similar nature of results that water stress reduces the nitrogen use efficiency and indirectly leaves more nitrogen in the soil.

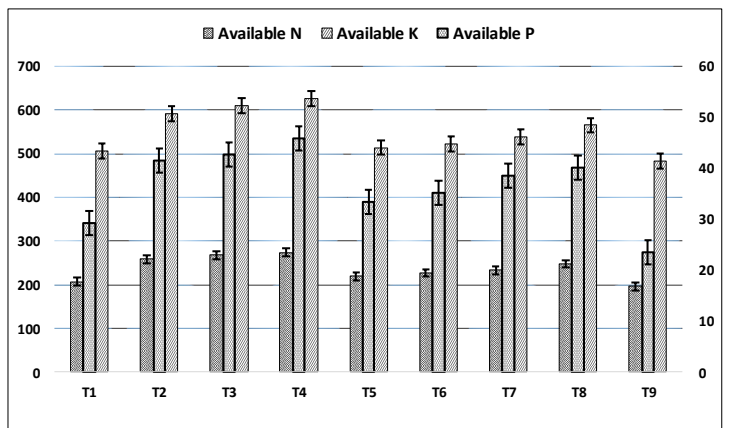

Figure 1. Post-harvest available nutrient status (kg/ha) during Kuruvai, 2019 season

The soil available nutrient status of phosphorus and potassium were also fell in the same trend. The discussion made in the above also holds good here also. Reduced uptake in the treatments $T_{4}$ and $T_{3}$ due to the moisture stress left more nutrients in the soil.

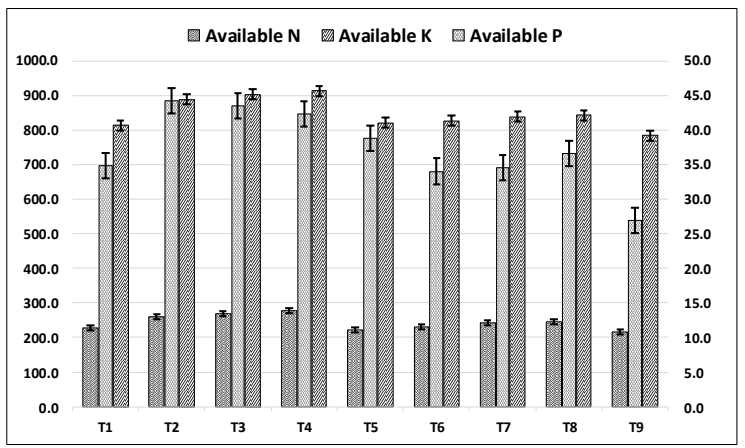

Figure 2. Post-harvest available nutrient status (kg/ha) during Navarai, 2019-20 season

Due to availability of enough moisture, the rice plants in $T_{9}$ treatment exhausted the available nutrients especially phosphorus and potassium leaving lesser nutrients in soil.

\section{CONCLUSION}

The varied duration of moisture stress at panicle initiation and flowering stages significantly altered the total drymatter production ( $\mathrm{kg} / \mathrm{ha})$, nutrient uptake of rice and soil available nutrient status after the harvest of crop. Higher total drymatter production was observed in the treatment $T_{9}$ treatment (maintaining saturation of water for entire life period as in SRI) compared to all other treatments and lower total drymatter production was produced by the plants under stress period of 25 days at PI stage $\left(\mathrm{T}_{4}\right)$ due to prolonged stress period at PI stage. Nutrient uptake (N, P and $\mathrm{K}$ ) in grain, straw and in total rice plant was higher in $T_{9}$ compared to all other stress imposed treatments. Lower uptake was found in $\mathrm{T}_{4}$ (Moisture stress for 25 days at panicle initiation stage) and $\mathrm{T}_{3}$ (Moisture stress for 25 days at panicle initiation stage) treatments indicating the detrimental influence on nutrient uptake. The opposite trend was noted with respect to post-harvest soil available nutrient status. Hence, two seasons field study confirms that increasing the period water stress either at panicle initiation stage or at flowering stage reduced the nutrient uptake; but, panicle initiation stage is more detrimental than flowering stage in respect to drymatter accumulation, nutrient uptake in tropical condition of Tamil Nadu.

\section{REFERENCES}

CPG, 2012. Crop Production Guide. Department of Agriculture, Govt. of Tamil Nadu, Chennai and Tamil Nadu Agricultural University, Coimbatore

FAO, 2005. Food and Agricultural Organization of the United Nations. OECD-FAO Agricultural Outlook; OECD: Paris, France, pp. 2011-2030.

Germani, C., José, M. B. P., Kelly, D., Jacob, L and T.S. Jaqueline. 2016. Rice development and water demand under drought stress imposed at distinct growth stages. African J. Agricul. Res., 11(41): 4147-4156.

Ghosh, U., Chatterjee, A. and E. Bremer. 2018. Determining the moisture and plant effect on nutrient release, and plant nutrient uptake using ion exchange resin membrane. Commun. Soil Sci. Plant Analysis, 49(7): 782-790.

Gomez, K.A., and A.A. Gomez. 2010. Statistical procedures for agricultural research Vol. $2^{\text {nd }}$ Ed. Wiley India Pvt Ltd., New Delhi, India.

Goswami, S. B., Mondal, R. and S. K. Mandi. 2019. Crop residue management options in rice-rice system: A review. Archives Agron. Soil Sci., 66(9): 1218-1234.

Havlin, J. L., Tisdale, S. L., Nelson, W.L. and J. D. Beaton. 1997. Soil fertility and fertilizers: An introduction to nutrient management,. $5^{\text {th }}$ ed. Prentice Hall of India Private Limited, New Delhi.

Haefele, S.M., Jabbar, S.M.A. and J.D.L.C. Siopongco. 2008. Nitrogen use efficiency in selected rice (Oryza sativa L.) genotypes under different water regimes and nitrogen levels. Field Crop Res., 107: 137-146.

Jiang, P., Cai, F., Zhao, Z.Q., Meng, Y., Gao, L.Y. and T.H. Zhao. 2018. Physiological and drymatter characteristics of spring maize in northeast China under drought stress. Water, 10(11), 1561 
Kaleeswari, R. K., Maragatham, S. and M. R. Latha. 2012. Direct and residual effect of phosphorus sources and manures on yield and nutrient uptake by rice in Alfisols. Madras Agric. J., 99: 37-39.

Koffler, B. E., Luschin-Ebengreuth, N., Stabentheiner, E., Müller, M. and B. Zechmann. 2014. Compartment specific response of antioxidants to drought stress in Arabidopsis. Plant Sci., 227: 133-144.

Liu, X., Fan, Y., Long, J., Wei, R., Kjelgren, R., Gong, C. and J. Zhao. 2013. Effects of soil water and nitrogen availability on photosynthesis and water use efficiency of Robinia pseudoacacia seedlings. J. Environ. Sci., 25(3): 585-595.

NRRI, 2018. Annual Report 2017-18. ICAR-National Rice Research Institute, Cuttack, Odisha, India.

Teronpi, L. and B. Bharali. 2019. Management of nitrogen for enhancing physiological efficiency in upland rice (Oryza sativa L.) under water stress condition. J. Pharmacognosy Phytochem., 8(2): 1898-1902. 